\begin{tabular}{|c|c|c|}
\hline Iso & $\begin{array}{c}\text { Bulletin of Pharmaceutical Sciences } \\
\text { Assiut University }\end{array}$ & \\
\hline 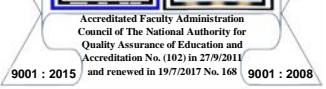 & $\begin{array}{l}\text { Website: http://bpsa.journals.ekb.eg/ } \\
\text { e-mail: bullpharm@aun.edu.eg }\end{array}$ & $\begin{array}{c}\text { BULL. PHARM. SCI. } \\
\text { Assiut univ. }\end{array}$ \\
\hline
\end{tabular}

\title{
ANTI-OXIDANT AND ANTI-BACTERIAL ACTIVITIES OF SINAPIS ALBA L. (LEAVES, FLOWERS AND FRUITS) GROWN IN SYRIA
}

\author{
Racha Khatib and Kinan Al-Makky* \\ Department of Pharmacognosy and Medicinal Plants, Faculty of Pharmacy, Damascus \\ University, Damascus, Syria
}

\begin{abstract}
This research aims to determine the phenolic and flavonoid contents in the extracts of the Sinapis alba L. parts and to calculate the free radical scavenging and antibacterial activity of them. The highest phenolic content was $28.302 \mathrm{mg} / \mathrm{g}$ dry plant, the highest flavonoid content was $2.072 \mathrm{mg} / \mathrm{g}$ dry plant in the methanolic flower extract. In interaction with diphenyl picryl hydrazyl, the inhibitory concentrations of half of free radicals ranged from $2.836 \mathrm{mg} / \mathrm{mL}$ in the methanolic fruit extract to $17.853 \mathrm{mg} / \mathrm{mL}$ in the chloroform flower extract. Methanolic extracts showed a zone of inhibition against Staphylococcus aureus, the diameters of the inhibition zone were $17.2 \mathrm{~mm}$ in leaf and fruit extracts, and $15 \mathrm{~mm}$ in flower extract at a concentration of 700 $\mathrm{mg} / \mathrm{mL}$. The study showed that the methanolic extracts of Sinapis alba L. have good phenolic and flavonoid contents, good free radical scavenging activity and have antibacterial activity against Staphylococcus aureus.
\end{abstract}

\section{INTRODUCTION}

Plants have been used in the treatment of many diseases and they have formed an important resource for medicinal preparations ${ }^{1}$. The family Brassicaceae (Cruciferae) contains over 330 genera and about 3,700 species including mustard which importance has increased recently. There are three species of mustard: White mustard (Sinapis alba L.), brown mustard (Sinapis nigra L.) and oriental (Sinapis juncea L.) $)^{2}$.

Sinapis alba L. is a widespread plant in the Mediterranean region and has great economic and medical importance due to its anti-tumor and insecticidal properties $^{3}$. The major compounds of Sinapis alba L. are glucosinolates, fatty oil, proteins and phenyl propane derivatives. It has been used in the treatment of common cold, bronchitis, rheumatism and in the treatment of inflammation of the respiratory tract and the gastrointestinal tract in homeopathy, but it should be avoided in children under 6 years, gastrointestinal ulcers and inflammatory kidney diseases $^{4}$. Mustard has high amounts of antioxidants, vitamins (B complex) and minerals (Calcium, magnesium, iron, potassium and selenium $)^{5}$.

Sinapis alba L. seeds contain of fatty acid (41.3\% Erucic acid), glucosinolates, and phenolic acids ( $P$-Hydroxy benzoic acid, transSinapic, trans- Caffeic, and trans- Ferulic) ${ }^{6}$. Kaempferol is the main flavonoid in the leaves extract of the plant, and there are isorhamntin and quercetin ${ }^{7}$. Phenols and flavonoids have antioxidant activity, these natural antioxidants have anti-cancer properties, inhibit apoptosis and reactive oxygen species (ROS) generation and have free radical scavenging activity ${ }^{8}$. Mustard leaves extract decreases the damage of oxidative stress by reducing the level of oxygen radicals?

White mustard has anti proliferative, proapoptotic, antioxidant and antimicrobial properties. It can be used as a food preservative because mustard glucosinolates reduce bacterial growth in salad packages, which leads to increasing vegetables' shelf life. In addition, it can be regarded as a part in anticancer therapy 
because of its low toxicity ${ }^{10}$. The plant has antibacterial activity against Staphylococcus aureus and no activity against Escherichia coli and Pseudomonas aeruginosa because Gramnegative bacteria are more resistant than Grampositive bacteria ${ }^{11}$.

The aim of this study was to compare between leaves, flowers and fruits of Sinapis alba L. which is widespread in Syria and estimate the phenolic and flavonoid contents in the extracts of parts of the plant as well as to determine the 2,2-diphenyl-1picryl hydrazyl (DPPH) scavenging activity and antibacterial activity against some selected pathogenic bacteria.

\section{MATERIALS AND METHODS}

\section{Plant material}

The plant was collected between January and April 2019 between 8 and 9 AM from different areas of Damascus and its countryside. It was identified by Dr. Imad Kadi, Department of Plant Biology, Faculty of Science, Damascus University.

The plant parts (leaves, flowers, and fruits) were separated from each other and dried at room temperature for 14 days in the shade and were powdered in an electric grinder (Multimaxy, GR-1000, Taiwan) to prepare the plant extracts.

\section{Preparation of plant extracts}

Plant parts powder $(25 \mathrm{~g})$ was placed in the Soxhlet device, and the extraction was performed by adding $600 \mathrm{ml}$ of solvent (methanol $70 \%$ and chloroform), at $60^{\circ} \mathrm{C}$, for 6 hours, the extract was filtered with filter paper (Zelpa, Belgium). Solvent was removed using a rotatory evaporator under vacuum at $60^{\circ} \mathrm{C}(\mathrm{RV}$ 10 digital IKA, Germany) and then put in the shaking incubator (JSSI-100C -JSR, India) at $40^{\circ} \mathrm{C}$ with stirring until the weight was relatively constant. The crude extracts were stored at $6^{\circ} \mathrm{C}$ in airtight containers. The process was repeated three times for each sample and yields were calculated. The extraction yield was calculated by the following equation:

Yield\% $\%$ (weight of dry extract/ weight of dry powdered plant material) $\times 100$.

\section{Determination of total phenolic contents in the plant extracts}

The method published by Abdeltaif S et al. was applied to determine total phenolic contents in samples ${ }^{12} .20 \mu 1$ of extract was mixed with $1.58 \mathrm{ml}$ of distilled water and 300 $\mu 1$ of $20 \%$ sodium carbonate and $100 \mu$ of Folin-Ciocalteu reagent (Merck KGaA Darmstadt, Germany). The blank was concomitantly prepared, containing $2 \mathrm{ml}$ ethanol. The samples were mixed and then left in a dark place at room temperature for $45 \mathrm{~min}$, the absorbance was measured at $765 \mathrm{~nm}$ (UVVIS Spectrophotometer (T80+), PG Instruments, United Kingdom). The total phenols were identified by a calibration curve of gallic acid in ethanol within the concentration range 0-500 mg/l (Fig.1). Means were calculated from three parallel analyses as gallic acid equivalents in $\mathrm{mg} / \mathrm{g}$ of dry plant.

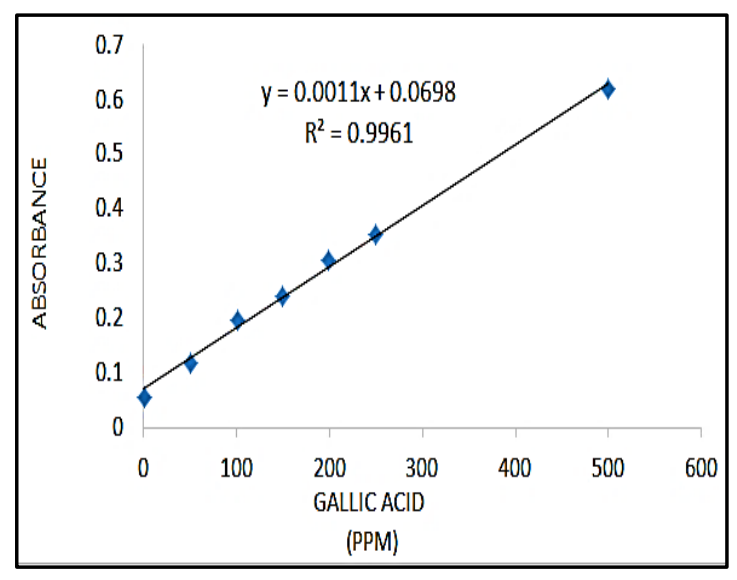

Fig.1: Calibration curve of gallic acid.

\section{Determination of total flavonoid contents in the plant extracts}

Aluminum chloride colorimetric method was used to determine total flavonoid contents in samples as mentioned by Kitaz A, $2017^{13}$. One $\mathrm{ml}$ of extract was mixed with $1 \mathrm{ml}$ of aluminum trichloride 2\% (Riedel-de Haen, Germany). The blank was concomitantly prepared, containing $2 \mathrm{ml}$ methanol. The samples were mixed and then left in a dark place at room temperature for $30 \mathrm{~min}$, the absorbance was measured at $464 \mathrm{~nm}$ (UV-VIS Spectrophotometer (T80+), PG Instruments, United Kingdom). The calibration curve was produced within the concentration range 0-40 $\mathrm{mg} / \mathrm{l}$ of quercetin (Fig.2). Means were 
calculated from three parallel analyses as quercetin equivalents in $\mathrm{mg} / \mathrm{g}$ of dry plant.

\section{Evaluation of DPPH scavenging activity}

The free radical scavenging capacity of Sinapis alba L. extracts against DPPH (Tokyo Chemical Industry, Japan) was measured based on Alhajali $\mathrm{O}$ et al., 2021 method $^{14} .300 \mu 1$ of each concentration of extract was mixed with 3 $\mathrm{ml}$ of $45 \mu \mathrm{g} / \mathrm{ml}$ ethanolic solution containing DPPH radicals. The samples were mixed and then left in the dark for $30 \mathrm{~min}$, and the absorbance was measured at $518 \mathrm{~nm}$ (UV-VIS Spectrophotometer (T80+), PG Instruments, United Kingdom). The calibration curve was produced within the concentration range of 9$175 \mu \mathrm{g} / \mathrm{ml}$ of ascorbic acid (Fig.3). Results were calculated by preparing a series of concentrations (0.5- 1 - 2- 3- 4- $5 \mathrm{mg} / \mathrm{ml}$ ) from each extract and showed as $\mathrm{IC}_{50}$ (the inhibitory concentration of half of free radicals). The percentage of scavenging activity was calculated using the following equation:

DPPH scavenging activity

$$
(\%)=\left(\mathrm{A}_{\text {control }}-\mathrm{A}_{\text {sample }}\right) / \mathrm{A}_{\text {control }} \times 100 \text {. }
$$

Where:

$\mathrm{A}_{\text {control: }}$ The absorbance of control (Ethanol + DPPH)

$\mathrm{A}_{\text {sample }}$ : The absorbance of sample (Extract + DPPH).

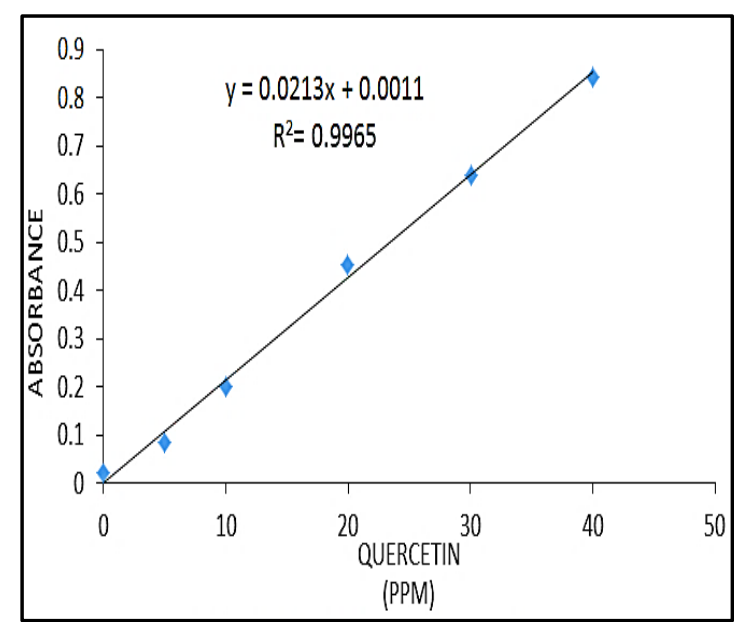

Fig. 2: Calibration curve of quercetin

\section{Bacterial strains}

Pathogenic bacterial strains

(Staphylococcus aureus as Gram - positive, and Escherichia coli, Pseudomonas aeruginosa as Gram-negative) were isolated and identified in the Microbiology Laboratory, Department of Plant Biology, Faculty of Science, Damascus University. Strains were used to estimate the antibacterial activities of methanolic extracts of Sinapis alba L.

\section{Antibacterial activity}

The method reported by Perez C et al. was applied to examine Sinapis alba L. methanolic extracts against Staphylococcus aureus, Escherichia coli, and Pseudomonas aeruginosa by agar well diffusion method ${ }^{15}$. The nutrients broth agar (Liofilchem, Italy), was inoculated with the selected bacteria and incubated for $24 \mathrm{~h}$ at $37^{\circ} \mathrm{C}$. Sterile cotton swabs were dipped in the bacterial suspension (the microbial turbidity was equal to 0.5 McFarland) and uniformly streaked over the entire surface of the MuellerHinton agar. This procedure was repeated by streaking three times and rotating the petri dish about 60 degrees after each time. Finally, the rim of the agar was swabbed. Dry methanolic extracts were dissolved in absolute Dimethyl Sulfoxide (DMSO) to prepare a series of concentrations $(200,300,500,700 \mathrm{mg} / \mathrm{ml})$. Four wells with a diameter of $7 \mathrm{~mm}$ were punched in each plate with a sterile cork borer. $60 \mu \mathrm{l}$ of extract was introduced into the well ${ }^{16}$. Antibiotic susceptibility testing discs (Cefaclor, levofloxacin, tobramycin, and gentamicin) were used as positive controls, while DMSO was used as negative control. All petri diches were incubated for $24 \mathrm{~h}$ at $37^{\circ} \mathrm{C}$. The antibacterial activity of the Sinapis alba L. methanolic extracts was interpreted as inhibition zone diameters surrounding the wells $(\mathrm{mm})$.

\section{Statistical analysis}

SPSS software program, version 26 was used for statistical analysis.

Two-Way Analysis of Variance (ANOVA) test was used to define the significance of differences between Sinapis alba L. parts in the determination of total phenols and flavonoids contents and free radical scavenging capacity.

T-Test was used to define the significance of differences between Sinapis alba L. parts and ascorbic acid in the determination of free radical scavenging capacity. 


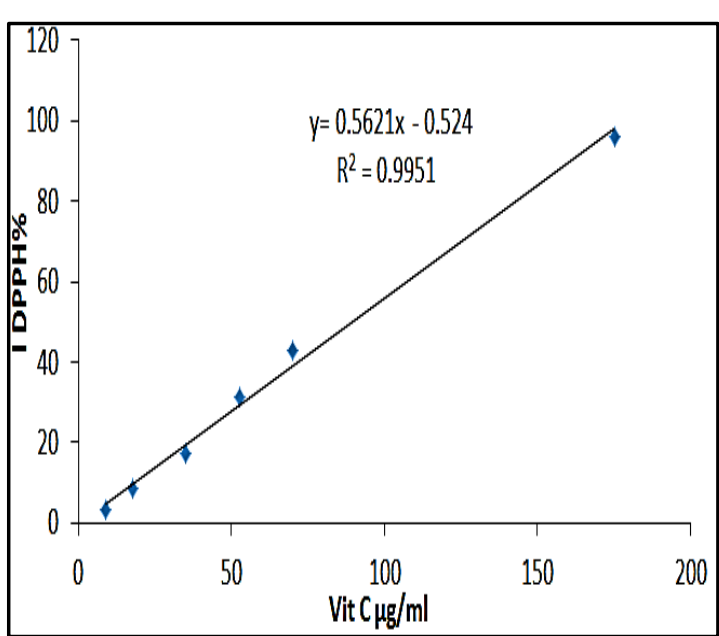

Fig. 3: Calibration curve of ascorbic acid.

One-Way ANOVA test was used to define the significance of differences between Sinapis alba L. parts in antibacterial activity.

For all previous tests, significance levels were $P<0.05$.

All tests were repeated three times and displayed as mean value \pm standard deviation using Microsoft Excel 2013.

The Pearson's correlation was performed for the relationship between extract concentration, total phenolic content, total flavonoid content and DPPH scavenging activity in each plant part. Correlation is significant at the 0.01 level.

\section{RESULTS AND DESCUSSION}

\section{RESULTS}

\section{Yield of extraction}

Yield of extraction ranged from $41.31 \%$ in the $70 \%$ methanolic flower extract to $4.39 \%$ in the chloroform extract of the fruits (Table1).

\section{Determination of total phenolic and flavonoid contents}

Phenolic compounds ranged from 28.302 $\mathrm{mg}$ gallic acid equivalents/ $\mathrm{g}$ dry plant in the methanolic flower extract to $1.596 \mathrm{mg}$ gallic acid equivalents/ $g$ dry plant in the chloroform extract of the fruits (Table1).

Flavonoid compounds ranged from 2.072 mg quercetin equivalents/ $g$ dry plant in the methanolic flower extract to $0.446 \mathrm{mg}$ quercetin equivalents/ $g$ dry plant in the chloroform extract of the fruits (Table1).

\section{Anti-Oxidant activity of Sinapis alba $L$. parts}

Inhibitory Concentration (IC50) ranged from $2.836 \mathrm{mg} / \mathrm{ml}$ in the methanolic fruit extract to $17.853 \mathrm{mg} / \mathrm{ml}$ in the chloroform extract of the flower (When calculating the percentage of inhibition at a concentration 2 $\mathrm{mg} / \mathrm{ml}$ it was ranging between 16.449 and $35.189 \%$ ) while ascorbic acid had IC50 value $0.09 \mathrm{mg} / \mathrm{ml}$ (Table1).

Pearson's correlation was 1.000 between extract concentration, total phenolic content, total flavonoid content each other's, while it was 0.793 between DPPH scavenging activity and other factors (Table 2).

There were no zones of inhibition against Escherichia coli.

Diameter of the inhibition zone against Staphylococcus aureus ranged between $12.2 \mathrm{~mm}$ in flowers extract to $17.2 \mathrm{~mm}$ in leaves and fruits extracts.

Diameter of the inhibition zone against Pseudomonas aeruginosa ranged between $7.5 \mathrm{~mm}$ at $200 \mathrm{mg} / \mathrm{ml}$ concentration to 10 $\mathrm{mm}$ at $700 \mathrm{mg} / \mathrm{ml}$ (Table3).

Table1: Phenol, flavonoid contents, and $\mathrm{IC}_{50}$ value of Sinapis alba L. parts and positive control.

\begin{tabular}{|c|c|c|c|c|c||}
\hline \multirow{2}{*}{ Solvent } & $\begin{array}{c}\text { Sinapis } \\
\text { alba L. } \\
\text { part }\end{array}$ & Yield \% & $\begin{array}{c}\text { Phenols (mg } \\
\text { gallic acid } \\
\text { equivalents/g dry } \\
\text { plant) }\end{array}$ & $\begin{array}{c}\text { Flavonoids }(\mathrm{mg} \\
\text { quercetin } \\
\text { equivalents/g dry } \\
\text { plant) }\end{array}$ & $\mathrm{IC}_{50}(\mathrm{mg} / \mathrm{ml})$ \\
\hline \multirow{2}{*}{$\begin{array}{c}\text { Methanol } \\
70 \%\end{array}$} & Leaves & $32.15 \pm 0.85$ & $19.282 \pm 0.222$ & $2.068 \pm 0.008$ & $3.963 \pm 0.001$ \\
\cline { 2 - 6 } & Flowers & $41.31 \pm 2.11$ & $28.302 \pm 0.467$ & $2.072 \pm 0.014$ & $2.872 \pm 0.001$ \\
\cline { 2 - 6 } & Fruits & $33.42 \pm 0.10$ & $22.007 \pm 0.393$ & $1.354 \pm 0.012$ & $2.836 \pm 0.001$ \\
\hline \multirow{3}{*}{ Chloroform } & Leaves & $6.52 \pm 0.24$ & $2.179 \pm 0.023$ & $1.425 \pm 0.002$ & $7.374 \pm 0.002$ \\
\cline { 2 - 6 } & Flowers & $7.52 \pm 0.39$ & $1.811 \pm 0.012$ & $0.458 \pm 0.003$ & $17.853 \pm 0.002$ \\
\cline { 2 - 6 } & Fruits & $4.39 \pm 0.09$ & $1.596 \pm 0.007$ & $0.446 \pm 0.003$ & $10.972 \pm 0.090$ \\
\hline \multicolumn{7}{|c|}{ Ascorbic acid } & $0.09 \pm 0.000$ \\
\hline
\end{tabular}

Values are mean \pm standard deviation 


\section{DISCUSSION}

\section{Yield of extraction}

Yields of methanolic extracts were higher than chloroform extract yields, this may be due to the plant material, which contains elevated levels of polar compounds that dissolve in methanol because of its higher polarity than chloroform $^{17}$.

\section{Determination of total phenolic and flavonoid contents}

The importance of these calibrations is to determine the differences between Sinapis alba L. grown in Syria and global Sinapis alba L.

Results of total phenolic contents agree with the content of Vergun O et al., 2019 who studied ethanol leaf extract of white mustard that contains total phenols content $73.58 \mathrm{mg}$ gallic acid/g dry extract ${ }^{18}$. Nevertheless,

Zhang D et al., 2019 estimated total phenols content of ethanol seeds extract to be $53.2 \mathrm{mg}$ gallic acid/ g dry extract, which is lower than the previous results ${ }^{19}$.

Total flavonoid contents of this study were lower than flavonoids found by Vergun $\mathrm{O}$ et al., 2019 which were measured as 62.91 mg quercetin/ g dry extract, this may be caused by different plant environment or different calibration method ${ }^{18}$.
Anti-Oxidant activity of Sinapis alba $L$. parts

Methanolic fruit extract had the highest free radical scavenging activity, this may be due to the high content of antioxidants in seeds which are in the fruits (like vitamin E, sterols, phosphatides and omega 3$)^{20}$.

Free radicals scavenging activity results are compatible with Ronak F, 2016 and Mayengbam S et al., 2014 $21 \& 22$.

The percentage of inhibition of free radicals in white mustard seed methanol extract was calculated by Mayengbam S et al., 2014, it was $39 \%$ at concentration $2 \mathrm{mg} / \mathrm{ml}^{22}$. However, the percentage of inhibition of white mustard powder ranged from 15 to $36 \%$ at a concentration of $1 \mathrm{mg} / \mathrm{ml}$ according to Ronak F, $2016^{21}$.

The statistically significance level value of Two-Way ANOVA Test was $(\mathrm{P}=0.000<$ 0.05), which indicates that there was a statistically significant difference between methanolic and chloroform extracts.

The statistically significance level value of T-Test was (P> 0.05) in methanolic extracts, which indicates that there was not a statistically significant difference between methanolic extracts and ascorbic acid.

Table2: Pearson's correlation between extract concentration, total phenolic content, total flavonoid content and DPPH scavenging activity

\begin{tabular}{||c|c|c|c|c||}
\hline & $\begin{array}{c}\text { Extract } \\
\text { concentration }\end{array}$ & $\begin{array}{c}\text { Total phenolic } \\
\text { content }\end{array}$ & $\begin{array}{c}\text { Total flavonoid } \\
\text { content }\end{array}$ & $\begin{array}{c}\text { DPPH scavenging } \\
\text { activity }\end{array}$ \\
\hline Extract concentration & 1 & $1.000^{* *}$ & $1.000^{* *}$ & $0.793^{* *}$ \\
\hline Total phenolic content & $1.000^{* *}$ & 1 & $1.000^{* *}$ & $0.793^{* *}$ \\
\hline $\begin{array}{c}\text { Total flavonoid } \\
\text { content }\end{array}$ & $1.000^{* *}$ & $1.000^{* *}$ & 1 & $0.793^{* *}$ \\
\hline $\begin{array}{c}\text { DPPH scavenging } \\
\text { activity }\end{array}$ & $0.793^{* *}$ & $0.793^{* *}$ & $0.793^{* *}$ & 1 \\
\hline
\end{tabular}

**Correlation is signifiant at the 0.01 level 
Table3: The zone of inhibition of Sinapis alba L. extracts and controls against selected bacteria

\begin{tabular}{|c|c|c|c|c|}
\hline \multirow[b]{2}{*}{$\begin{array}{l}\text { Sinapis alba } \\
\text { L. part }\end{array}$} & \multirow[b]{2}{*}{ Concentration } & \multicolumn{3}{|c|}{ Diameter of inhibition zone ( $\mathrm{mm}$ ) } \\
\hline & & Escherichia coli & $\begin{array}{c}\text { Staphylococcus } \\
\text { aureus }\end{array}$ & $\begin{array}{c}\text { Pseudomonas } \\
\text { aeruginosa }\end{array}$ \\
\hline \multirow{4}{*}{ Leaves } & $200 \mathrm{mg} / \mathrm{ml}$ & ND & $14.0 \pm 0.0$ & $7.5 \pm 0.0$ \\
\hline & $300 \mathrm{mg} / \mathrm{ml}$ & ND & $15.0 \pm 0.0$ & $8.0 \pm 0.0$ \\
\hline & $500 \mathrm{mg} / \mathrm{ml}$ & ND & $16.0 \pm 0.0$ & $9.0 \pm 0.0$ \\
\hline & $700 \mathrm{mg} / \mathrm{ml}$ & ND & $17.2 \pm 0.2$ & $10.0 \pm 0.0$ \\
\hline \multirow{4}{*}{ Flowers } & $200 \mathrm{mg} / \mathrm{ml}$ & ND & $12.2 \pm 0.2$ & $7.5 \pm 0.0$ \\
\hline & $300 \mathrm{mg} / \mathrm{ml}$ & ND & $13.0 \pm 0.0$ & $8.0 \pm 0.0$ \\
\hline & $500 \mathrm{mg} / \mathrm{ml}$ & ND & $14.0 \pm 0.0$ & $9.0 \pm 0.0$ \\
\hline & $700 \mathrm{mg} / \mathrm{ml}$ & ND & $15.0 \pm 0.0$ & $10.0 \pm 0.0$ \\
\hline \multirow{4}{*}{ Fruits } & $200 \mathrm{mg} / \mathrm{ml}$ & ND & $13.2 \pm 0.2$ & $7.5 \pm 0.0$ \\
\hline & $300 \mathrm{mg} / \mathrm{ml}$ & ND & $15.0 \pm 0.0$ & $8.0 \pm 0.0$ \\
\hline & $500 \mathrm{mg} / \mathrm{ml}$ & ND & $16.0 \pm 0.0$ & $9.0 \pm 0.0$ \\
\hline & $700 \mathrm{mg} / \mathrm{ml}$ & ND & $17.2 \pm 0.2$ & $10.0 \pm 0.0$ \\
\hline Cefaclor & $30 \mu \mathrm{g}$ & $\begin{array}{l}\text { ND } \\
(\mathrm{R})\end{array}$ & $\begin{array}{c}35.0 \pm 0.0 \\
(\mathrm{~S})\end{array}$ & $\begin{array}{l}\mathrm{ND} \\
(\mathrm{R}) \\
\end{array}$ \\
\hline Levofloxacin & $5 \mu \mathrm{g}$ & $\begin{array}{l}9.0 \pm 0.1 \\
(\mathrm{R})\end{array}$ & $\begin{array}{c}29.0 \pm 0.2 \\
(\mathrm{~S})\end{array}$ & $\begin{array}{c}31.0 \pm 0.0 \\
(\mathrm{~S})\end{array}$ \\
\hline Tobramycin & $10 \mu \mathrm{g}$ & $\begin{array}{c}11.0 \pm 0.0 \\
(\mathrm{R})\end{array}$ & $\begin{array}{c}20.0 \pm 0.3 \\
(S)\end{array}$ & $\begin{array}{c}19.0 \pm 0.2 \\
(S)\end{array}$ \\
\hline Gentamicin & $10 \mu \mathrm{g}$ & $\begin{array}{l}13.0 \pm 0.2 \\
\text { (I) }\end{array}$ & $\begin{array}{l}21.0 \pm 0.3 \\
(\mathrm{~S})\end{array}$ & $\begin{array}{c}21.0 \pm 0.0 \\
(\mathrm{~S})\end{array}$ \\
\hline DMSO & - & $\begin{array}{l}\text { ND } \\
(\mathrm{R})\end{array}$ & $\begin{array}{l}\text { ND } \\
(\mathrm{R})\end{array}$ & $\begin{array}{l}\text { ND } \\
(\mathrm{R})\end{array}$ \\
\hline
\end{tabular}

Values are mean inhibition zone $(\mathrm{mm}) \pm$ standard deviation

ND: Not Detected. R: Resistance. I: Intermediate. S: Sensitive

The statistically significance level value of $\mathrm{T}$-Test was $(\mathrm{P}<0.05)$ in chloroform extracts, which indicates that there was a statistically significant difference between chloroform extracts and ascorbic acid.

Extract concentration, total phenolic content, total flavonoid content and DPPH scavenging activity in each plant part showed significantly positive correlation. This means that concentration of extract; total phenols and flavonoids have an important role in DPPH scavenging activity of Sinapis alba L. because poly phenols have a reducing role due to its hydroxyl groups, which gives it hydrogendonating property ${ }^{23}$

\section{Anti-Bacterial activity of Sinapis alba $\mathbf{L}$. parts}

The zones of inhibition with diameter less than $12 \mathrm{~mm}$ were considered as having no antimicrobial activity, diameters between 12 and $16 \mathrm{~mm}$ were considered moderately active and with $16 \mathrm{~mm}$ were considered highly active according to Sujatha A et al., 20135. These mean no antimicrobial activity against Escherichia coli and Pseudomonas aeruginosa.

All extracts have moderate activity against Staphylococcus aureus except leaves and fruits extracts, which at $700 \mathrm{mg} / \mathrm{ml}$ concentration, have high activity.

Gram-negative bacteria (Like Escherichia coli and Pseudomonas aeruginosa) have an envelope which is made of three layers (Outer membrane, peptidoglycan cell wall and inner membrane). This envelope gives bacteria impermeable and resistant properties 24 .

These results are similar to Camacho $\mathrm{C}$ et al., 2019 and Ronak F, 2016, but Weldu H et al., 2019 displayed higher activity against Staphylococcus aureus and Escherichia coli $^{11 \& 21 \& 25}$.

According to previous studies the increasing of extract concentrations have a direct relation to give a high antimicrobial activity due to the increase in phenols, flavonoids and glucosinolates contents ${ }^{26}$. 
The statistically significance level value of One-Way ANOVA Test was $(\mathrm{P}=0.151>$ $0.05)$, which indicates that there was not a statistically significant difference between the extracts of plant parts, the reason could be that all parts have similar concentrations of the active compounds which are given the antimicrobial activity.

\section{Conclusion}

This study concluded that the methanolic extracts of Sinapis alba L. have good phenolic and flavonoid contents, good free radical scavenging activity and have anti-bacterial activity against Staphylococcus aureus but not against Escherichia coli or Pseudomonas aeruginosa. There was no statistically significant difference between the plant parts studied, so any part of them can be used in the food and pharmaceutical industries.

\section{Acknowledgment}

This research was supported by Damascus University, College of Pharmacy, Department of Pharmacognosy and Medicinal Plants. The authors wish to thank Damascus University, College of Science, Department of Plant Biology for helping in classification of the plant species and giving bacterial strains.

\section{REFERENCES}

1. R. Joujeh, "Phytochemical and Biological Study of Centaurea cineraria L. Cultivated in Syria", Bulletin of Pharmaceutical Sciences, Assiut University, 43 (2), 141-147 (2020).

2. M. Mizani, M. Yousefi, S. Rasouli, A. Sharifan and M. Bamani Moghaddam, "The effect of different deheating processes on residual mirosinase activity, antimicrobial properties and total phenolic contents of yellow mustard (Sinapis alba)", Journal of Food Biosciences and Technology, Islamic Azad University, Science and Research Branch, 6 (2), 1 - 12 (2016).

3. M. Al-Qudah, H. Al-Jaber, R. Muhaidat, E. Hussein, A. AlAbdeHamid, M. AlSmadi, I. Abaza, F. Afifi and S. AbuOrabi, "Chemical composition and antimicrobial activity of the essential oil from Sinapis alba L. and Sinapis arvensis L. (Brassicaceae) growing wild in Jordan", Research Journal of Pharmaceutical, Biological and Chemical Sciences, 2(4), 1136-1144 (2011).

4. T. Fleming, J. Gruenwald, T. Brendler and C. Jaenicke, "PDR for Herbal Medicines" Medical Economics Company, Montvale, United States of America, 2000; Fourth edition, p.805806.

5. A. Sujatha, Ravishankar, Mariajancyrani, Chandramohan, "Preliminary phytochemical investigation and antimicrobial activity of Sinapis alba", Scholars Journal of Applied Medical Sciences, 1(3), 138-141 (2013).

6. H. Kozlowska, D.A. Rotkiewicz and R. Zadernowski, "Phenolic acids in rapeseed and mustard", Journal of the American Oil Chemists' Society, 60(6), 1119-1123 (1983).

7. J. Onyilagha, A. Bala, R. Hallett, M. Gruber, J. Soroko and N. Westcott, "Leaf flavonoids of the cruciferous species, Camelina sativa, Crambe spp., Thlaspi arvense and several other genera of the family Brassicaceae", Biochemical Systematics and Ecology, 31(11), 13091322 (2003).

8. A. K. Esmaeili, R.M. Taha, S. Mohajer and B. Banisalam, "Antioxidant Activity and Total Phenolic and Flavonoid Content of Various Solvent Extracts from In Vivo and In Vitro Grown Trifolium pratense L. (Red Clover)", BioMed Research International, 2015(Article ID 643285), 1 - 11 (2015).

9. S. Kumar and A. Andy, "Health promoting bioactive phytochemicals from Brassica", International Food Research Journal, 19(1), 141-152 (2012).

10. V. Boscaro, L. Boffa, A. Binello, G. Amisano, S. Fornasero, G. Cravotto and M. Gallicchio, "Antiproliferative, proapoptotic, antioxidant and antimicrobial effects of Sinapis nigra L. and Sinapis alba L. extracts", Molecules, 23 (11), 1 - 17 (2018).

11. C. M. A. Camacho, J. Arias-Palacios, A. O. E, Rodriguez AOE, "Assessment of the antibacterial capacity of Sinapis alba L. by the method of plates and wells", 
Pharmacology On Line, 2, 329 - 335 (2019).

12. S. Abdeltaif, K. SirElkhatim and A. Hassan, "Estimation of phenolic and flavonoid compounds and antioxidant activity of spent coffee and black tea" , waste for potential recovery and reuse in Sudan Recycling, 3 (27), 1-9 (2018).

13. A. Kitaz, "Comparison of the total phenol, flavonoid content and antioxidant activity of methanolic roots extracts of Asphodelus microcarpus and Asphodeline lutea growing in Syria", International Journal of Pharmacognosy and Phytochemical Research, 9(2), 159-164 (2017).

14. O. Alhajali and A. Ali-Nizam, "Phytochemical Screening and Antibacterial Activity of Pistacia atlantica and Pinus canariensis Leaf Extracts", Journal of the Turkish Chemical Society A, 8(2), 403-418 (2021).

15. C. Perez, M. Pauli and P. Bazerque, "An Antibiotic Assay by the Agar Well Diffusion Method", Acta Biologiae et Medicinae Experimentalis, 15, 113-115 (1990).

16. M. Balouiri, M. Sadiki and S.K. Ibnsouda, "Methods for in vitro evaluating antimicrobial activity: A review", Journal of Pharmaceutical Analysis, 6 (2), 71-79 (2016).

17. D. H. Truong, D. H. Nguyen, N. T. Anh Ta, A. V. Bui, T. H. Do and H. C. Nguyen, "Evaluation of the use of different solvents for phytochemical constituents, antioxidants, and in-vitro anti-inflammatory activities of Severinia buxifolia", Journal of Food Quality, 2019 (Article ID 8178294), 1- 9 (2019).

18. O. Vergun, D. Rakhmetov, O. Shymanska, V. Fishchenko, E. Ivanishova and J. Brindza, "Leaves extracts of selected crops as potential source of antioxidants", Plant Introduction, 84(4), 82 - 88 (2019).
19. D. Zhang, R. Y. Gan, A. K. Farha, G. Kim, Q. Q. Yang, X. M. Shi, C. L. Shi, Q. X. Luo, X. B. Xu, H. B. Li and H. Corke, "Discovery of antibacterial dietary spices that target antibiotic-resistant bacteria", Microorganisms, 7(6), 1- 23 (2019).

20. R. P. Yadav and B. Kumari, "Ultrasonic Studies on Mustard Oil: A Critical Review", International Journal of Science and Research, 4(8), 517-531 (2015).

21. F. Ronak, Antioxidant and Antibacterial Properties of Endogenous Phenolic Compound from Commercial Mustard Products, Master's Dissertation, University of Manitoba, Winnipeg, Canada, 55 - 75 (2016).

22. S. Mayengbam, A. Aachary and U. Thiyam - Hollander, "Endogenous phenolics in hulls and cotyledons of mustard and canola: A comparative study on its sinapates and antioxidant capacity", Antioxidants, 3 (3), 544 - 558 (2014).

23. Z. Kefayati, S. M. Motamed, A. Shojaii, M. Noori and R. Ghods, "Antioxidant Activity and Phenolic and Flavonoid Contents of the Extract and Subfractions of Euphorbia splendida Mobayen", Pharmacognosy Research, 9 (4), 362 365 (2017).

24. Z. Breijyeh, B. Jubeh and R. Karaman, "Resistance of Gram-Negative Bacteria to Current Antibacterial Agents and Approaches to Resolve It", Molecules, 25(6), 1-23 (2020).

25. H. Weldu, A. Mehari and L. Alem, "Evaluation of antimicrobial activities of Sinapis alba and Brassica nigra leaves against selected microorganisms", Pharmaceutical and Biosciences Journal, 7 (2), 01- 06 (2019).

26. F. D. Gonelimali, J. Lin, W. Miao, J. Xuan, F. Charles, M. Chen and S. R. Hatab, "Antimicrobial Properties and Mechanism of Action of Some Plant Extracts Against Food Pathogens and Spoilage Microorganisms", Frontiers in Microbiology, 9 (1639), 1- 9 (2018). 


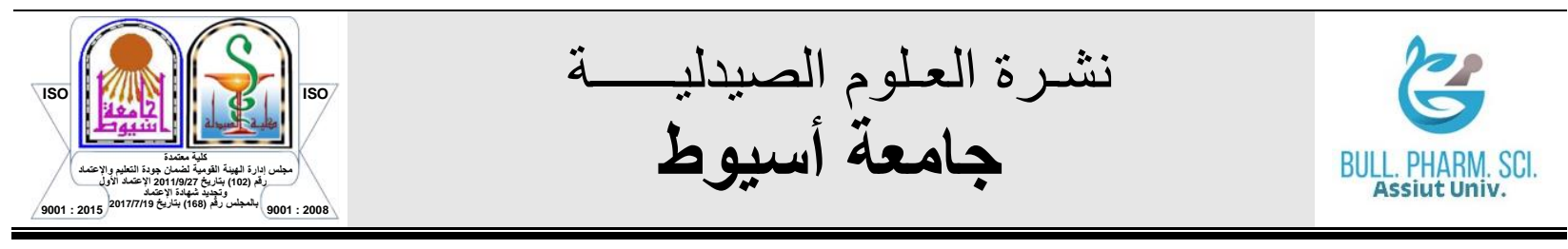

\section{النشاط المضاد للتأكسد والمضاد للجراثيم في أوراق وأزهار وثمار نبات الخردل الأبيض النامي في سوريا أفيا}

$$
\text { رشا خطيب - كنان المكي }
$$

قسم العقاقير والنباتات الطبية ، كلية الصيدلة ، جامعة دمشق ، دمثق ، سوريا

يـهدف البحث إلى المقارنة بين أجزاء الخردل الأبيض الذي ينمو في سوريا ، وتحديد المحتوى

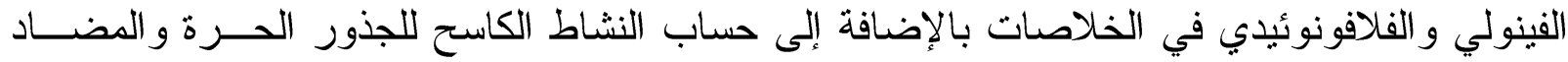

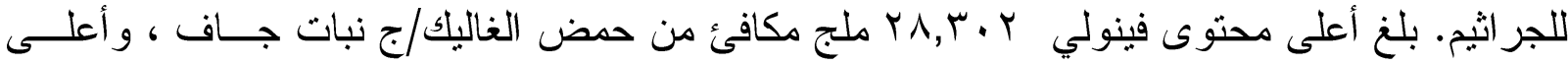

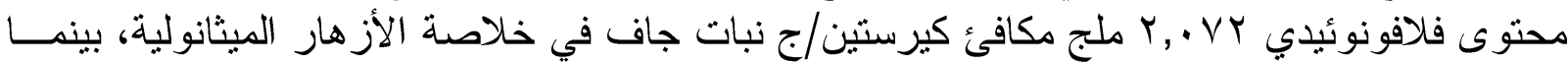

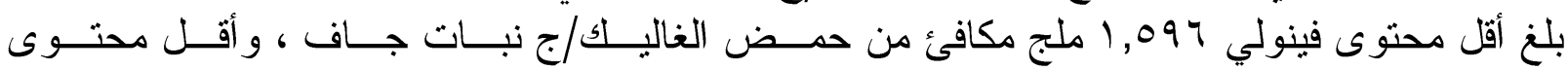

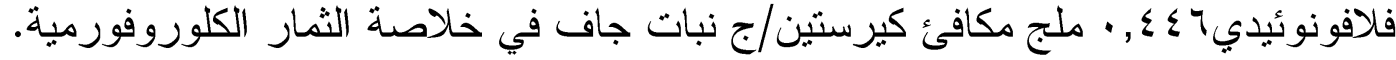

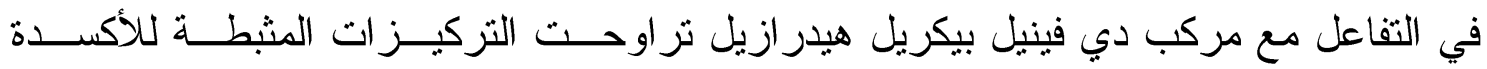

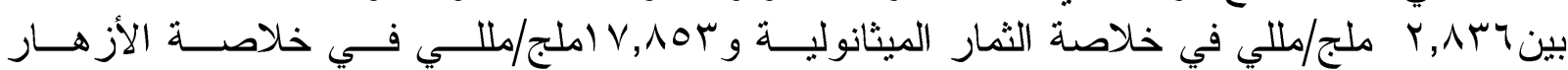

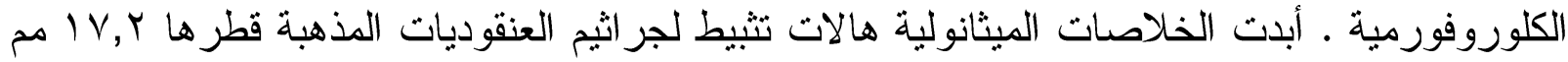

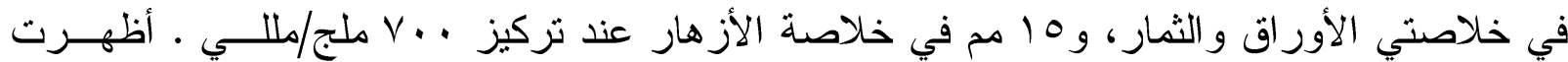

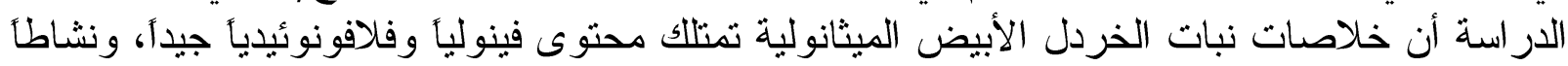
كاسحاً للجذور الحرة ، وفعالية مضادة لجر اثيم العنقوديات المذهبة. 